\title{
The Proteome of the Differentiating Mesencephalic Progenitor Cell Line CSM14.1 In Vitro
}

\author{
B. Weiss, ${ }^{1}$ S. Haas, ${ }^{1}$ G. Lessner, ${ }^{1,2}$ S. Mikkat, ${ }^{3}$ M. Kreutzer, ${ }^{3}$ M. O. Glocker, ${ }^{3}$ \\ A. Wree, ${ }^{1}$ and 0. Schmitt $^{1}$ \\ ${ }^{1}$ Department of Anatomy, University of Rostock, Gertrudenstraße 9, 18057 Rostock, Germany \\ ${ }^{2}$ Department of Pathology, University of Würzburg, Josef-Schneider Straße 2, 97080 Würzburg, Germany \\ ${ }^{3}$ Proteome Center Rostock, University of Rostock, Schillingallee 69, 18055 Rostock, Germany
}

Correspondence should be addressed to O.Schmitt; schmitt@med.uni-rostock.de

Received 5 July 2013; Accepted 16 December 2013; Published 30 January 2014

Academic Editor: Stephan M. Huber

Copyright (C) 2014 B. Weiss et al. This is an open access article distributed under the Creative Commons Attribution License, which permits unrestricted use, distribution, and reproduction in any medium, provided the original work is properly cited.

\begin{abstract}
The treatment of Parkinson's disease by transplantation of dopaminergic (DA) neurons from human embryonic mesencephalic tissue is a promising approach. However, the origin of these cells causes major problems: availability and standardization of the graft. Therefore, the generation of unlimited numbers of DA neurons from various types of stem or progenitor cells has been brought into focus. A source for DA neurons might be conditionally immortalized progenitor cells. The temperature-sensitive immortalized cell line CSM14.1 derived from the mesencephalon of an embryonic rat has been used successfully for transplantation experiments. This cell line was analyzed by unbiased stereology of cell type specific marker proteins and 2D-gel electrophoresis followed by mass spectrometry to characterize the differentially expressed proteome. Undifferentiated CSM14.1 cells only expressed the stem cell marker nestin, whereas differentiated cells expressed GFAP or NeuN and tyrosine hydroxylase. An increase of the latter cells during differentiation could be shown. By using proteomics an explanation on the protein level was found for the observed changes in cell morphology during differentiation, when CSM14.1 cells possessed the morphology of multipolar neurons. The results obtained in this study confirm the suitability of CSM14.1 cells as an in vitro model for the study of neuronal and dopaminergic differentiation in rats.
\end{abstract}

\section{Introduction}

The motoric cardinal symptoms (rigor, tremor, akinesia, and postural instability) in Parkinson's disease (PD) are caused by the degeneration of dopaminergic (DA) neurons. Most of these dopaminergic neurons are located in the substantia nigra pars compacta. The classical, symptomatic treatment of the disease includes the use of pharmaceuticals like L-DOPA or the more invasive deep brain stimulation. Furthermore, over the last three decades the concept of cell replacement has been brought into focus. In various clinical trials postmitotic DA neurons from human embryonic mesencephalic tissue have demonstrated to be the most prospective cells for transplantation in human PD brains $[1,2]$.

However, the origin of these cells from human embryos causes their major limitation concerning tissue availability and standardization of the graft. Therefore, to establish cell replacement therapy as an available therapeutic option for many PD patients, other ways to generate DA neurons in unlimited number and consistent quality have to be found. Over the last years various protocols for the production of DA neurons, for example, from embryonic stem cells or foetal neuronal stem cells, have been used. Another approach is the generation of DA neurons via induced pluripotent stem cells [3]. However, the use of conditionally immortalized progenitor cells is also a promising approach due to nearly unlimited access of material [4].

The temperature-sensitive immortalized mesencephalic progenitor cell line CSM14.1 derived from a 14-day-old rat embryo [5-8] differentiates in vitro in tyrosine hydroxylase (TH) and aldehyde-dehydrogenase-2 (ALD2)-expressing neurons. Undifferentiated CSM14.1 cells also contain the stem cell marker nestin and also the expression of Nurr$1-$ a member of the superfamily of orphan nuclear retinoic 
acid receptors - which plays an important role in the differentiation of dopaminergic neurons, has been described [9]. During differentiation the cells also show a change from an epithelial fibroblast-like phenotype to a morphology resembling multipolar neurons. After transplantation into the striatum of neonatal hemiparkinsonian rats the differentiation into TH-expressing cells and an improvement in motoric function could be demonstrated [10].

In contrast to the above mentioned results concerning the characterization of CSM14.1 cells in vitro obtained by using immunocytochemistry and western blotting, by the use of proteomic approaches important issues such as protein amount, protein stability, subcellular localization of proteins, posttranslational modifications, and protein-protein interactions can be elucidated [11]. Therefore, in this study we investigated the ability of the cell line CSM14.1 to function as a model for the neuronal and dopaminergic differentiation in rats by combining unbiased stereological evaluation of cell type specific marker proteins with 2D-gel electrophoresis followed by mass spectroscopy to analyze the differentially expressed proteome.

\section{Material and Methods}

2.1. Cell Culture and Immunocytochemistry. Immortalized CSM14.1 cells [5] were cultivated and expanded as described by Haas and Wree [9] in DMEM supplemented with $10 \%$ fetal calf serum (FCS), 100 Units $\mathrm{mL}^{-1}$ penicillin, and $100 \mu \mathrm{g} \mathrm{mL}^{-1}$ streptomycin in a humidified incubator $\left(95 \%\right.$ air, $5 \% \mathrm{CO}_{2}$, $33^{\circ} \mathrm{C}$ ). Cell passage was done every third day. To induce differentiation the amount of FCS was reduced to $1 \%$ and the temperature was risen to $39^{\circ} \mathrm{C}$-nonpermissive temperature $[12,13]$. The media was routinely changed every third day. All cell tissue reagents were obtained from Gibco Invitrogen Corporation, Carlsbad, CA, USA.

2.2. For Immunocytochemistry CSM14.1 Cells Were Cultivated in 24 Well Plates. Undifferentiated cells and cells after 14 days and 28 days of differentiation, respectively, (see above) were washed with $0.1 \mathrm{M}$ PBS ( $\mathrm{pH} 7.4$ ) and fixed in $3.7 \%$ paraformaldehyde solution (solved in 0.1 M PBS, $\mathrm{pH}$ 7.4) for a minimum of one hour. After three washes with PBS ( $\mathrm{pH} 7.4$ ) the cells were preincubated for 60 minutes in PBS ( $\mathrm{pH} 7.4$ ) containing 3\% bovine serum albumine (BSA), $0.025 \%$ Triton $\mathrm{X}-100$, and $3 \%$ normal horse serum (NHS) to block unspecific binding sites.

Incubation with the primary antibodies directed against the neural stem cell protein (nestin, mouse monoclonal, 1:500, BD Biosciences, San Jose, CA, USA), glial fibrillary acidic protein (GFAP, mouse monoclonal, 1:400, SigmaAldrich Corporation, St. Louis, MO, USA), neuronal nuclei antigen (NeuN, mouse monoclonal, 1:1000, Chemicon, Billerica, MA, USA), and tyrosine hydroxylase (TH clone 2, mouse monoclonal, 1:500, Sigma-Aldrich) dissolved in $0.1 \mathrm{M}$ PBS containing $0.025 \%$ Triton X-100 and $1 \%$ BSA was done at $4^{\circ} \mathrm{C}$ overnight. For each time point and antibody four independent experiments were performed. After washing for three times with PBS ( $\mathrm{pH}$ 7.4) the cells were incubated with the Cy3-conjugated secondary antibody (Donkey antimouse IgG + IgM, 1:500, Jackson ImmunoResearch Laboratories, Inc., West Grove, PA, USA) dissolved similar to primary antibodies at $4^{\circ} \mathrm{C}$ overnight. For cell counting the cell nuclei were stained with 4.6-diamidino-2-phenylindol dihydrocloride (DAPI, Carl Roth GmbH + Co.KG, Karlsruhe, Germany).

For the various cell type specific markers four different culture wells per marker were examined for each of the three different groups, leading to the examination of 48 cell culture wells.

2.3. Cell Counting and Statistics. Microphotography and cell counting were performed with an Olympus BX 51 microscope and the Stereo Investigator v8.0 (MicroBrightField Bioscience, Vermont, USA) software. Cells were counted using the 10x objective and an unbiased counting frame [14]. A characteristic point of a cell was applied to decide if the cell should be counted. Hereby the cell nuclei were chosen. Quantification was performed in region of the whole cell culture well that was placed under the circular cover slip (diameter $1.2 \mathrm{~cm}$ ). Counting frames had a dimension of $500 \times 500 \mu \mathrm{m}^{2}$ and a distance to each other of $1000 \mu \mathrm{m}$. A systematic random sampling, controlled by the Stereo Investigator software, ensured that frame regions were not double counted. An average of about 500 cells per culture well were examined during the counting procedure. The ChiQuadrat test and Fisher's exact test were used (SPSS v11.01, SPSS Inc. IBM Company Headquarters, Chicago, IL, USA) to compare cell counts.

2.4. Proteomics. For proteomics CSM14.1 cells were cultivated and differentiated in tissue culture dishes as described above. After removal of the culture medium undifferentiated cells (day 0 ) and cells after 28 days of differentiation (day 28) were washed twice with ice cold PBS ( $\mathrm{pH} 7.4$ ). Afterwards the cells were mechanically removed from the bottom of the tissue culture dishes in $1 \mathrm{~mL}$ ice cold PBS each. The cell suspension was fractionated in $1.5 \mathrm{~mL}$ reaction tubes which underwent centrifugation for $5 \mathrm{~min}$ at $4^{\circ} \mathrm{C}$ and $5000 \mathrm{rpm}$ (Heraeus Megafuge 1.0R, Thermo Fisher Scientific Inc., Waltham, MA, USA, Rotor 3041). The remaining mass of each cell pellet was approximately $150 \mathrm{mg}$. After freezing at $-80^{\circ} \mathrm{C}(9 \times$ probe mass $(\mathrm{mg})) \mu \mathrm{L}$ lysis buffer (containing $7 \mathrm{M}$ urea (Sigma-Aldrich), $2 \mathrm{M}$ thiourea (SigmaAldrich), $70 \mathrm{mM}$ DTT (Sigma-Aldrich), 4\% w/v CHAPS (Sigma-Aldrich), 0.5\% ampholyte high resolution ph 3-10 $($ Sigma-Aldrich $)),(0.4 \times$ mass probe $(\mathrm{mg})) \mu \mathrm{L}$ Complete (Roche Diagnostics $\mathrm{GmbH}$, Basel, Swiss), $(0.1 \times$ probe mass (mg)) $\mu$ L PMSF (Sigma-Aldrich), and (0.1× probe mass $(\mathrm{mg}))$ $\mu \mathrm{L}$ PepA (Sigma-Aldrich) were added. The tubes were quickly frozen in liquid nitrogen, warmed up at room temperature, sonificated in an ice cold ultrasound bath for $5 \mathrm{~min}$ and then centrifuged for $20 \mathrm{~min}$ at $4^{\circ} \mathrm{C}$ and $15.000 \mathrm{rpm}$ (Megafuge 1.0R, Rotor 3041). Protein concentration was measured using a Bradford solution by Sigma-Aldrich. Sample aliquots were stored at $-80^{\circ} \mathrm{C}$. 
The isoelectric focussing (IEF) procedure was performed with $18 \mathrm{~cm}$ nonlinear Immobiline DryStrip $\mathrm{pH}$ 3-10 (GE Healthcare Bio-Sciences AB, Uppsala, Sweden) which was rehydrated at $20^{\circ} \mathrm{C}$ for $20 \mathrm{~h}$. Each strip was loaded with $500 \mu \mathrm{g}$ protein using cup-loading technology at anode and cathode. Electric focussing was performed with a Protean IEF Cell (Bio-Rad Laboratories, Inc., Hercules, CA, USA) at $8000 \mathrm{~V}$ resulting in approximately $100 \mathrm{kV}$ h. Furthermore, IEF strips were incubated with equilibration buffer containing $1.5 \mathrm{M}$ Tris- $\mathrm{HCl} \mathrm{pH} 8.8,6 \mathrm{M}$ urea, 30\% glycerol, $2 \%$ SDS, and $64.8 \mathrm{mM}$ DDT for $30 \mathrm{~min}$ followed by a second incubation with the same buffer containing $20 \mathrm{mM} 2$-VP instead of DTT. Second dimension was carried out on $12 \%$ SDS gels using a Protean Plus Dodeca Cell (BioRad) at $125 \mathrm{~V}$ and $12^{\circ} \mathrm{C}$ for approximately $16 \mathrm{hrs}$. Afterwards gels were fixed with $45 \%$ methanol and $1 \%$ acetic acid for $24 \mathrm{hrs}$. Staining was performed using Brilliant-Blue Coomassie G250 (Carl Roth). For digitization at $300 \mathrm{dpi} / 12$ bit a Heidelberg Nexscan F4100 (Heidelberger Druckmaschinen, Heidelberg, Germany) was used. For further analysis the program Progenesis PG 200 version 2006 (Nonlinear Dynamics Ltd., Newcastle, Great Britain) was applied.

Image analysis was performed using Progenesis PG200 Version 2006 (Nonlinear Dynamics Ltd., Newcastle upon Tyne, U.K.). Two groups of experimental gels (6 gels from day 0 and 6 gels from day 28) were registered to a reference gel chosen from day 0 gels. Spots showing a 2.5-fold larger or lower spot volume in 5 or 6 different gels of each group were considered up- or downregulated. Absent spots were defined as spots found in 5 or 6 gels of the day 28 group and not found in any gel of the day 0 group and the reference gel.

Spot picking, in-gel enzymatic digestion of proteins, and MALDI-TOF-MS analysis were performed as described circumstantially in Lessner et al. [15]. For protein identification the UniProtKB/Swiss-Prot database was used.

\section{Results}

3.1. Immunocytochemistry and Cell Counting. The type VI intermediate filament (IF) protein nestin is a widely-used marker for neuronal progenitor cells. As compared to previous studies $[9,16]$, here we also demonstrate that a large portion of undifferentiated CSM14.1 cells was immunoreactive for nestin (Figure 1(a)) and that during differentiation the number of nestin-immunoreactive cells decreased (Figures 1(b), 1(c), and 2(a)). The results of unbiased stereological cell counting revealed a significant decrease of nestin-containing cells from $38.74 \%( \pm 0.62)$ at day zero to $11.46 \%( \pm 0.53)$ at 14 days of differentiation $(P<0.001)$. The number of nestinimmunoreactive cells after 28 days of differentiation was $15.09 \%( \pm 3.72)$ (Figure $2(\mathrm{a})$ ) and was significantly lower than at day zero $(P<0.001)$ but did not significantly differ from day 14 (Figure 2).

GFAP, a member of type III IF proteins, is known as an important and obligatory protein of astrocytes [17]. Undifferentiated CSM14.1 cells were not immunoreactive for GFAP in this study (Figure $1(\mathrm{~d})$ ), whereas after 14 and 28 days of differentiation, respectively, an increase in GFAPimmunoreactivity was observed (Figures 1(e) and 1(f)). The amount of GFAP-containing cells 14 days after differentiation was $18.72 \%( \pm 2.54)$ and this number increased to $19.66 \%( \pm 2.04) 28$ days after differentiation (Figure 2(b)). At both time points of differentiation the number of GFAPcontaining cells was significantly different $(P<0.001)$ from the starting point but not significantly different between 14 and 28 days of differentiation. However, an increase in fluorescence intensity in GFAP-immunoreactive cells over time was observed indicating higher contents of GFAP after 28 days of differentiation.

A commonly used marker for postmitotic nerve cells is the neuronal nuclear protein NeuN with unknown function. In undifferentiated CSM14.1 cells the expression of NeuN could not be detected (Figure 1(g)) but its content in the CSM14.1 cells increased constantly during differentiation (Figures 1(h) and 1(i)). After 14 days of differentiation the number of $27.56 \%( \pm 3.31)$ of cells was immunoreactive for NeuN (Figure 2(c)) and a further increase up to $64.06 \%$ $( \pm 2.74)$ after 28 days of differentiation could be shown (Figures 1(i) and 2(c)). At both differentiation time points the NeuN-immunoreactive cell numbers were significantly higher compared to the starting point $(P<0.001)$ and the increase between 14 and 28 days of differentiation was also significantly different $(P<0.001)$.

A similar result was also found for $\mathrm{TH}$, the pacemaker enzyme of dopamine biosynthesis, which is a widely used protein to identify dopaminergic neurons. Undifferentiated CSM14.1 cells did not show any immunoreactivity for TH (Figure 1(j)). During differentiation TH was detectable after 14 days (Figure $1(\mathrm{k})$ ) and the number of TH-containing cells increased after 28 days (Figure 1(l)). Like for the GFAP immunofluorescence signal, the TH containing cells seemed to contain more of the epitope due to an increase of fluorescence intensity. After 14 days of cultivation at $39^{\circ} \mathrm{C} 12.07 \%$ $( \pm 1.71)$ of the cells were $\mathrm{TH}$-positive and a significant increase up to $55.69 \%( \pm 2.92)$ after 28 days of differentiation was detected (Figure 2(d)). At both differentiation time points the $\mathrm{TH}$-immunoreactive cell numbers were significantly higher compared to the starting point $(P<0.001)$ and the increase between 14 and 28 days of differentiation was also significantly different $(P<0.001)$.

3.2. Proteomics. In the reference gel 506 spots could be detected and $70.2 \%( \pm 5.3)$ of the spots from the experimental gels at day 0 could be matched onto the reference gel (Figure 3(a)). In contrast, only $49.2 \%( \pm 3.37)$ of the spots from the experimental gels at day 28 found a match on the reference gel (Figure 3(b)). Using the selection criteria as shown above, 27 spots were found upregulated in differentiated CSM14.1 cells, 24 spots downregulated, and 46 spots were detected as absent (i.e., only found in differentiated CSM14.1 cells). Via MALDITOF MS analysis 64 proteins could be identified (Table 1). The majority of proteins only detected in differentiated CSM14.1 cells (Figure 4(a)) were classified as regulating proteins $(17 \%)$, chaperons $(17 \%)$, and proteins against oxidative stress 


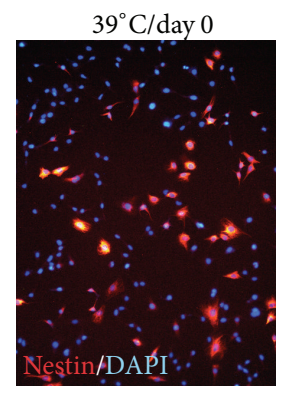

(a)

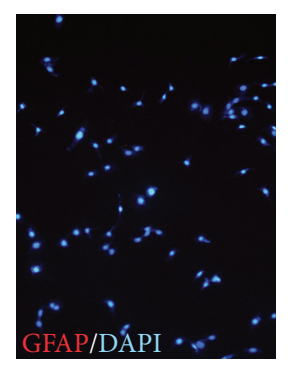

(d)

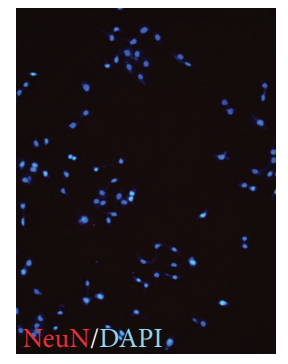

(g)

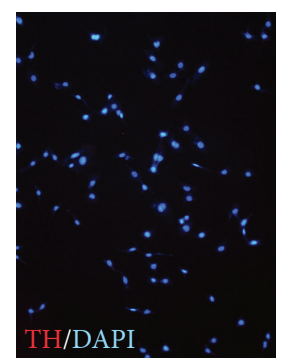

(j)

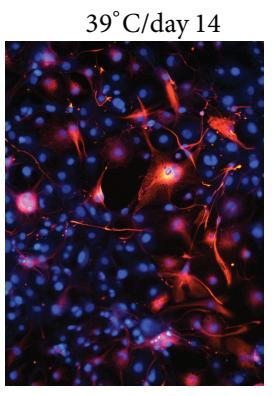

(b)

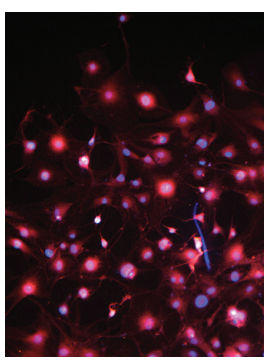

(e)

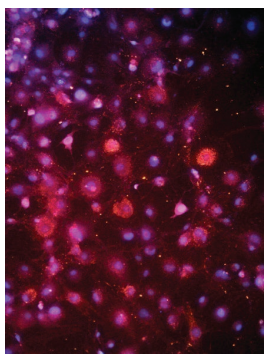

(h)

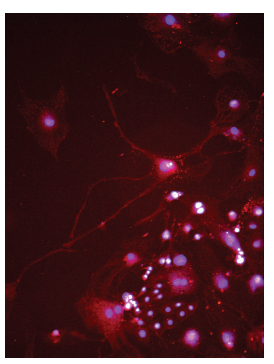

(k)

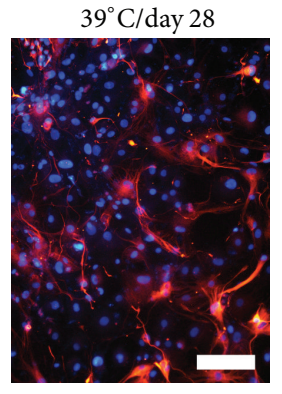

(c)

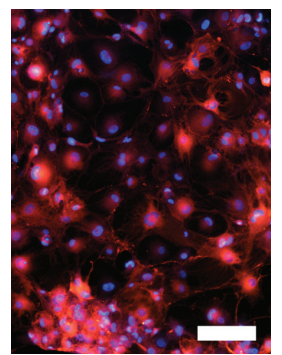

(f)

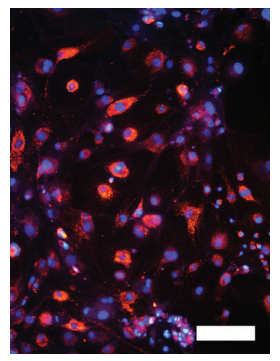

(i)

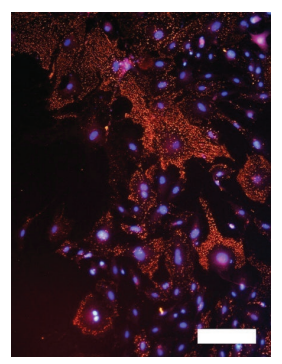

(l)

FIgURE 1: Results from ICC-staining of CSM14.1 cells during differentiation are shown. Images do not represent counting frame pictures and the numbers and distribution of immunoreactive cells should not be compared with the stereological results. However, morphological changes and different contents of cell type specific markers are recognizable. In the first row ((a), (b), (c)) images of staining against nestin (red) and DAPI (blue) are merged. A significant decrease of nestin-expression between undifferentiated cells (a) and cells that differentiated for 14 days (b) or 28 days (c) could be observed. In the second row ((d), (e), (f)) images of staining against GFAP (red) and DAPI (blue) are merged. Undifferentiated cells do not express GFAP (d). After 14 days of differentiation GFAP-positive cells could be detected (d) and an increase of positive cells could be shown after 28 days of differentiation (f). In the third row ((g), (h), (i)) images of staining against the neuronal marker NeuN (red) and DAPI (blue) are merged. No NeuN-positive cells could be detected in undifferentiated cells (g), whereas NeuN expressing cells could be found after 14 days of differentiation (h) and an increase in NeuN-positive cells could be observed after 28 days of differentiation (i). In the fourth row ((j), (k), (l)) images of staining against TH (red) and DAPI (blue) are merged. Undifferentiated cells do not express TH (j). TH-positive cells could be found after 14 days of differentiation (k) and an increase of TH-expressing cells was observed after 28 days of differentiation (l). Scale bars $=200 \mu \mathrm{m}((\mathrm{a})-(\mathrm{l}))$. 


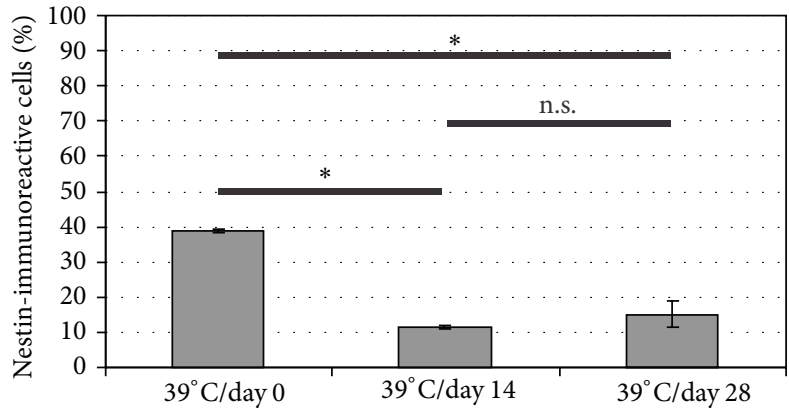

(a)

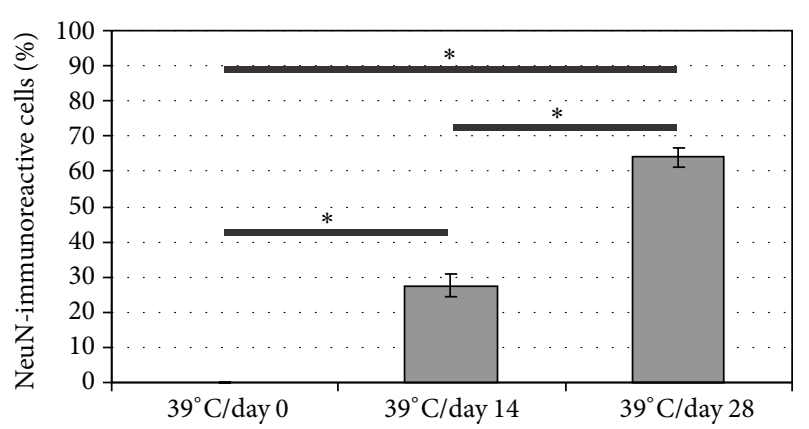

(c)

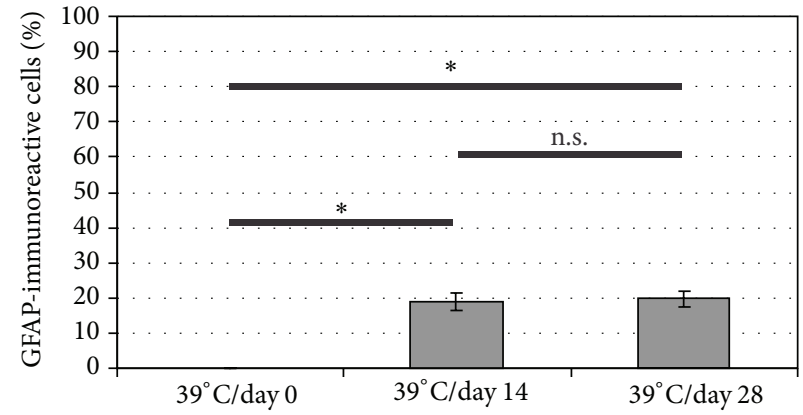

(b)

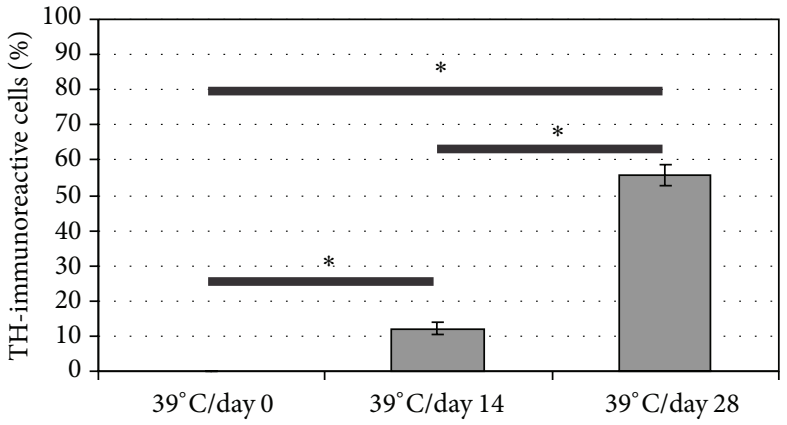

(d)

FIGURE 2: Results from unbiased cell counting are shown. In undifferentiated cells an amount of $38.74 \%( \pm 0.62)$ nestin-positive cells (a) was found. During differentiation a significant decrease in the amount of positive cells could be observed. After 14 days $11.46 \%$ ( \pm 0.53 ) and after 28 days $15.09 \%( \pm 3.72)$ of all cells were nestin-positive. GFAP (b) could not be detected in undifferentiated cells. After 14 days of differentiation $18.72 \%( \pm 2.54)$ of all cells were GFAP-immunoreactive. The amount of GFAP-immunoreactive cells did not change significantly after 28 days of differentiation up to $19.66 \%( \pm 2.04)$. Undifferentiated cells did not contain NeuN (c). After 14 days of differentiation $27.56 \%$ ( \pm 3.31 ) were NeuN-positive and a significant increase up to $64.06 \%( \pm 2.74)$ could be observed after 28 days of differentiation. TH (d) could not be found in undifferentiated cells, but a significant increase in the amount of TH-immunoreactive cells from $12.07 \%$ ( \pm 1.71$)$ after 14 days up to $55.69 \%$ ( \pm 2.92$)$ after 28 days of differentiation could be observed. Error bars show SEM. * Significant difference from the respective time point; $P<0.001$. For statistical analysis Chi-Quadrat test and Fisher's exact test were applied.

(17\%). Upregulated proteins (Figure 4(b)) belonged primarily to structural proteins $(31 \%)$, regulating proteins $(13 \%)$, chaperons $(13 \%)$, and proteins of energy metabolism $(13 \%)$. Proteins with a lower expression in differentiated CSM14.1 cells (Figure 4(c)) were classified as regulating proteins (40\%), proteins associated with transcription $(20 \%)$ and translation (20\%), and carbohydrate metabolism (20\%).

\section{Discussion}

4.1. Immunocytochemistry and Cell Counting. As a parallel approach by characterising the changes in the proteome of differentiating CSM14.1 cells we used various cell type specific antibodies to document the morphological and phenotypical alterations over time. Hereby we also used unbiased stereology to quantify the differences in immunoreactive cell numbers. Undifferentiated CSM14.1 cells were known to express the stem cell marker nestin [9]. In this study we were able to show that only $38.74 \%( \pm 0.62)$ of all cells are immunoreactive for nestin which is a contrary finding to the clonal origin of the cell line [5] and might be explained by proliferating cells in different phases of the cell cycle. After 28 days of differentiation $15.09 \%( \pm 3.72)$ of all cells still express nestin which indicates that differentiation may not be complete in all cells at this time point [18]. In this study GFAP could not be detected via immunocytochemistry in undifferentiated CSM14.1 cells which is a contrary finding to Vernon and Griffin [16], who demonstrated immunoreactivity in western blots and immunocytochemistry by using polyclonal antibodies against GFAP. Moreover, Vernon and Griffin [16] showed, after an initial increase of GFAP after two weeks of differentiation, a constant decrease below the GFAP content of undifferentiated cells. Our findings, by using a monoclonal primary antibody directed against GFAP, indicate that in undifferentiated CSM14.1 cells GFAP is not detectable but that under differentiation conditions about 20 percent of the cells contain GFAP. This discrepancy between the findings of Vernon and Griffin and our recent results could be explained by the use of polyclonal antibodies. The use of polyclonal antibodies in vivo and also in vitro is problematic due to the cause of the unspecific cross reactivity of antibodies produced 


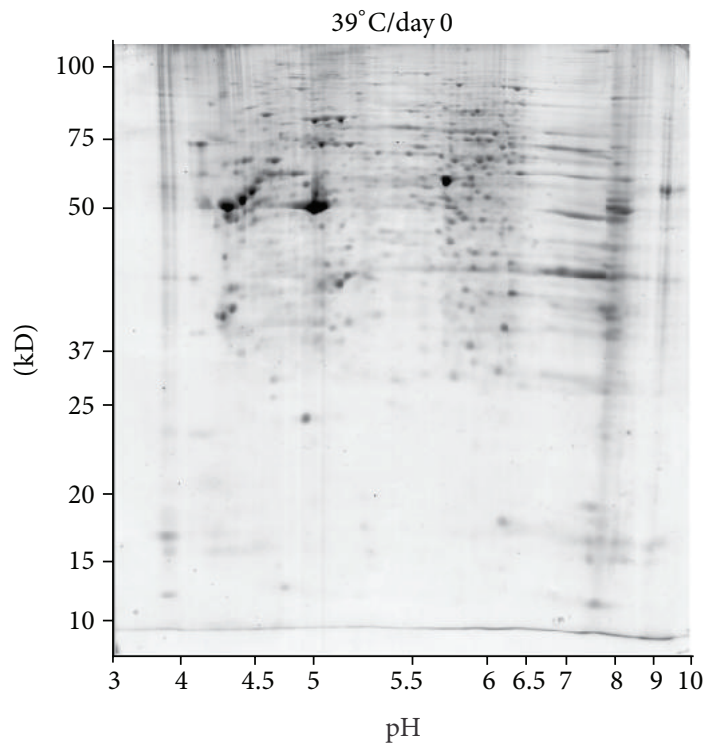

(a)

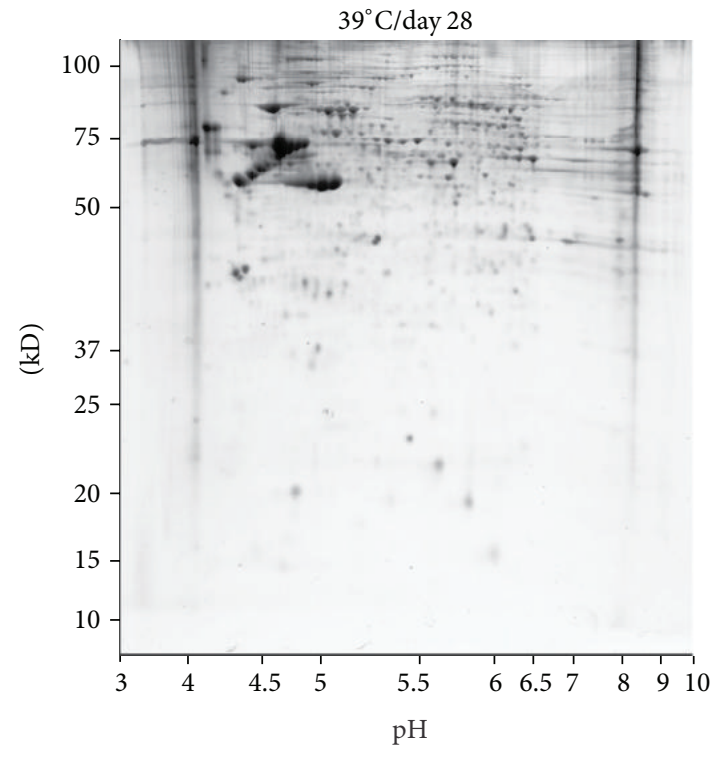

(b)

FIGURE 3: Comparison of 2 DE images of undifferentiated CSM14.1 cells (a) and of CSM14.1 cells after 28 days of differentiation (b). For spot visualization Coomassie-staining was used. Two groups of experimental gels (6 gels from day 0 and 6 gels from day 28) were registered to a reference gel chosen from day 0 gels. Spots showing a 2.5-fold larger or lower spot volume in 5 or 6 different gels of each group were considered up- or downregulated. Absent spots were defined as spots found in 5 or 6 gels of the day 28 group and not found in any gel of the day 0 group and the reference gel. In the reference gel 506 spots could be detected and $70.2 \%( \pm 5.3)$ of the spots from the experimental gels day 0 could be matched onto the reference gel. In contrast, only $49.2 \%( \pm 3.37)$ of the spots from the experimental gels day 28 found a match on the reference gel. Using the selection criteria as shown above, 27 spots were found upregulated in differentiated CSM14.1 cells, 24 spots downregulated, and 46 spots were detected as absent (i.e., only found in differentiated CSM14.1 cells). Via MALDI-TOF analysis 64 proteins could be identified.

from the serum of immunized animals [19]. The increase of neuronal markers and TH in differentiating CSM14.1 cells is in line with our previous studies [9] and with findings from other groups $[16,20]$.

Vernon and Griffin [16] showed that differentiated CSM14.1 cells express the neuron-specific, soluble nuclear protein NeuN at a significantly higher degree than undifferentiated CSM14.1 cells. In vivo NeuN-positive CSM14.1 cells were detectable after transplantation into the striatum of neonatal rats [10] or into the substantia nigra of adult hemiparkinsonian rats [21]. Assuming that CSM14.1 cells at permissive culture conditions $\left(33^{\circ} \mathrm{C}, 10 \% \mathrm{FCS}\right)$ are undifferentiated, these cells should not show immunoreactivity against NeuN, which could be demonstrated in the present study. Moreover, after 14 days of differentiation $27.56 \%$ of all cells were NeuN-positive. After 28 days of differentiation, there was a significant increase in immunoreactivity for $\mathrm{NeuN}$ up to $64.06 \%$. These results point to an increasing differentiation of CSM14.1 cells into neurons over the observed time period.

In differentiated CSM14.1 cells $\mathrm{TH}$, the pacemaker enzyme of dopamine biosynthesis, could be detected by western blotting $[9,16]$ and Vernon and Griffin [16] also achieved this by immunocytochemistry using a polyclonal antibody. In both works, a weak immunoreactivity for TH was also found in undifferentiated CSM14.1 cells by immunocytochemistry and western blots. In vivo TH-positive CSM14.1 cells were only detected after intrastriatal transplantation in neonatal rats [10].

In this study undifferentiated CSM14.1 cells showed no immunoreactivity for TH. This result is congruent with the results of NeuN and GFAP as shown above. There is also a significant increase in the amount of TH immunoreactive cells over the observed time period (12.07\% at day 14 and 55.69\% at day 28). The differences between our recent findings and the observations made by Vernon and Griffin in 2005 [16] might be explained by the use of a monoclonal antibody in our study. The detection of TH alone does not characterize a cell as dopaminergic, because dopamine can also be metabolized to the catecholamines epinephrine and norepinephrine $[22,23]$. However, the expression of the enzyme ALDH2 by differentiated CSM14.1 cells [9] makes a dopaminergic differentiation most likely, because ALDH2 could be used for the detection of differentiated dopaminergic cells [24-26]. Nevertheless, in the future the expression of the dopamine transporter in CSM14.1 cells or the content of dopamine itself in culture of differentiated CSM14.1 cells should be proofed.

4.2. Proteomics. In this study it was shown that the expression of the protein annexin A5 by the cell line CSM14.1 between day 0 (undifferentiated cells) and day 28 (differentiated cells) is upregulated. The same result has also been shown for the neuronal progenitor cell line ST14A derived from the 
TABLE 1: Differentially expressed proteins in CSM14.1 cells after 28 days of differentiation.

\begin{tabular}{|c|c|c|c|c|c|c|c|c|c|}
\hline Acc. No. & Entry name & Protein name & Expression & Score & MW & $\mathrm{pI}$ & $\mathrm{Qm}$ & Sc & Mixed \\
\hline \multicolumn{10}{|c|}{ Structural proteins } \\
\hline Q6AYZ1 & TBA1C_RAT & Tubulin alpha 1C-chain & Absent & 56 & 50590 & 4.96 & 4 & 11 & - \\
\hline P31000 & VIME_RAT & Vimentin & Up & 205 & 53757 & 5.06 & 24 & 36 & - \\
\hline P70615 & LMNB1_RAT & Lamin-B1 & Up & 188 & 66794 & 5.16 & 21 & 33 & - \\
\hline P60711 & ACTB_RAT & Actin, cytoplasmic 1 & Up & 110 & 42052 & 5.29 & 9 & 25 & - \\
\hline Q4V7C7 & ARP3_RAT & Actin related protein 3 & Up & 168 & 47783 & 5.61 & 15 & 36 & - \\
\hline P85108 & TBB2A_RAT & Tubulin beta 2A chain & Up & 92 & 50274 & 4.78 & 14 & 40 & + \\
\hline P48679 & LMNA_RAT & Lamin-A & Landmark & 401 & 74564 & 6.54 & 48 & 51 & - \\
\hline Q63610 & TPM3_RAT & Tropomyosin-alpha 3 chain & Landmark & 202 & 29217 & 4.75 & 18 & 43 & - \\
\hline P09495 & TPM4_RAT & Tropomyosin-alpha 4 chain & Landmark & 253 & 28549 & 4.66 & 19 & 47 & - \\
\hline \multicolumn{10}{|c|}{ Regulating proteins } \\
\hline Q5BKC9 & NGEF_RAT & Ephexin-1 & Absent & 55 & 81527 & 5.85 & 6 & 9 & - \\
\hline P62142 & PP1B_RAT & $\begin{array}{l}\text { Serine/threonine-protein phosphatase } \\
\text { PP1-beta catalytic subunit }\end{array}$ & Absent & 66 & 37961 & 5.84 & 5 & 19 & - \\
\hline 035763 & MOES_RAT & Moesin & Absent & 88 & 67868 & 6.16 & 10 & 16 & - \\
\hline P14668 & ANXA5_RAT & Annexin A5 & Up & 288 & 35779 & 4.93 & 20 & 54 & - \\
\hline Q68FP1 & GELS_RAT & Gelsolin & Up & 227 & 86413 & 5.76 & 24 & 31 & - \\
\hline O35814 & STIP1_RAT & Stress induced phosphoprotein 1 & Down & 160 & 63158 & 6.4 & 14 & 22 & - \\
\hline B3GNI6 & SEP11_RAT & Septin-11 & Down & 102 & 50005 & 6.24 & 8 & 21 & - \\
\hline P38983 & RSSA_RAT & $\begin{array}{l}\text { 40S ribosomal protein SA, laminin } \\
\text { receptor } 1, \mathrm{LRP} / \mathrm{LR} \text {; laminin-binding } \\
\text { protein precursor } \mathrm{p} 40\end{array}$ & Down & 51 & 32917 & 4.8 & 4 & 17 & - \\
\hline P85515 & ACTZ_RAT & Alpha-centractin & Down & 158 & 42701 & 6.19 & 11 & 40 & - \\
\hline Q99MZ8 & LASP1_RAT & Lim and SH3 domain protein 1 & Landmark & 126 & 30351 & 6.61 & 9 & 28 & - \\
\hline \multicolumn{10}{|c|}{ Transport proteins } \\
\hline Q9Z2L0 & VDAC1_RAT & $\begin{array}{l}\text { Voltage dependent anion selective } \\
\text { channel protein } 1\end{array}$ & Absent & 61 & 30851 & 8.62 & 4 & 19 & - \\
\hline $\mathrm{P} 02793$ & FRIL1_RAT & Ferritin light chain 1 & Absent & 140 & 20793 & 5.99 & 11 & 58 & - \\
\hline \multicolumn{10}{|c|}{ Chaperones } \\
\hline Q5XHZ0 & TRAP1_RAT & $\begin{array}{l}\text { Heat shock protein } 75 \mathrm{kDa}, \\
\text { mitochondrial }\end{array}$ & Absent & 118 & 80639 & 6.56 & 12 & 18 & - \\
\hline P28480 & TCPA_RAT & T-complex protein 1 subunit alpha & Absent & 115 & 60835 & 5.86 & 9 & 17 & - \\
\hline P52555 & ERP29_RAT & Endoplasmic reticulum protein ERp29 & Absent & 127 & 28614 & 6.23 & 8 & 31 & - \\
\hline Q66HD0 & ENPL_RAT & $\begin{array}{c}\text { Endoplasmin, heat shock protein } \\
90 \mathrm{kDa} \text { beta member } 1\end{array}$ & Up & 190 & 92998 & 4.72 & 25 & 31 & - \\
\hline P06761 & GRP78_RAT & $\begin{array}{l}78 \mathrm{kDa} \text { glucose-regulated protein, heat } \\
\text { shock } 70 \mathrm{kDa} \text { protein } 5\end{array}$ & Up & 307 & 72473 & 5.07 & 38 & 56 & - \\
\hline P18418 & CALR_RAT & Calreticulin & Landmark & 192 & 48137 & 4.33 & 18 & 46 & - \\
\hline P63018 & HSP7C_RAT & Heat shock cognate $71 \mathrm{kDa}$ protein & Landmark & 157 & 71055 & 5.37 & 22 & 39 & + \\
\hline P63039 & CH60_RAT & $\begin{array}{l}60 \mathrm{kDa} \text { heat shock protein, } \\
\text { mitochondrial }\end{array}$ & Landmark & 200 & 61088 & 5.91 & 20 & 42 & - \\
\hline P48721 & GRP75_RAT & Stress 70 protein & Landmark & 161 & 74097 & 5.97 & 25 & 41 & + \\
\hline Q68FQ0 & TCPE_RAT & T-complex protein 1 subunit epsilon & Landmark & 119 & 59955 & 5.51 & 18 & 28 & - \\
\hline \multicolumn{10}{|c|}{ Apoptosis } \\
\hline Q9QZA2 & PDC6I-RAT & $\begin{array}{l}\text { Programmed cell death 6-interacting } \\
\text { protein }\end{array}$ & Landmark & 299 & 97141 & 6.15 & 28 & 32 & - \\
\hline
\end{tabular}


TABle 1: Continued.

\begin{tabular}{|c|c|c|c|c|c|c|c|c|c|}
\hline Acc. No. & Entry name & Protein name & Expression & Score & MW & pI & Qm & Sc & Mixed \\
\hline \multicolumn{10}{|c|}{ Enzymes } \\
\hline \multicolumn{10}{|c|}{ Energy metabolism } \\
\hline P10719 & ATPB_RAT & $\begin{array}{l}\text { ATP synthase subunit beta, } \\
\text { mitochondrial }\end{array}$ & Absent & 146 & 56318 & 5.19 & 24 & 56 & + \\
\hline P50516 & VATA_MOUSE & $\begin{array}{c}\text { Vacuolar ATP synthase catalytic } \\
\text { subunit A }\end{array}$ & Up & 196 & 68625 & 5.42 & 23 & 36 & - \\
\hline P62815 & VATB2_RAT & $\begin{array}{l}\text { Vacuolar ATP synthase subunit B, } \\
\text { brain isoform }\end{array}$ & Up & 118 & 56857 & 5.57 & 13 & 28 & - \\
\hline P13803 & ETFA_RAT & $\begin{array}{l}\text { Electron transfer flavoprotein subunit } \\
\text { alpha, mitochondrial }\end{array}$ & Landmark & 49 & 35272 & 8.62 & 4 & 13 & - \\
\hline \multicolumn{10}{|c|}{ Carbohydrate metabolism } \\
\hline P11980 & KPYM_RAT & Pyruvate kinase isoenzyme M1/M2 & Absent & 175 & 58294 & 6.63 & 15 & 25 & - \\
\hline O88989 & MDHC_RAT & Malate dehydrogenase, cytoplasmic & Down & 69 & 36631 & 6.16 & 5 & 14 & - \\
\hline P07943 & ALDR_RAT & Aldose reductase & Down & 103 & 36230 & 6.26 & 10 & 26 & - \\
\hline P04797 & G3P_RAT & $\begin{array}{l}\text { Glyceraldehyde-3-phosphate } \\
\text { dehydrogenase }\end{array}$ & Landmark & 111 & 36090 & 8.14 & 9 & 31 & - \\
\hline P04764 & ENOA_RAT & Alpha enolase & Landmark & 233 & 47440 & 6.16 & 24 & 58 & - \\
\hline \multicolumn{10}{|c|}{ Amino acid metabolism } \\
\hline P0C2X9 & AL4A1_RAT & $\begin{array}{l}\text { Delta-1-pyrroline-5-carboxylate } \\
\text { dehydrogenase, mitochondrial }\end{array}$ & Absent & 166 & 62286 & 7.14 & 13 & 25 & - \\
\hline Q01205 & ODO2_RAT & $\begin{array}{c}\text { Dihydrolipoyllysine-residue } \\
\text { succinyltransferase component of } \\
\text { 2-oxoglutarate dehydrogenase complex }\end{array}$ & Absent & 84 & 49236 & 8.89 & 9 & 21 & - \\
\hline Q9JLJ3 & AL9A1_RAT & $\begin{array}{l}\text { 4-trimethylaminobutyraldehyde } \\
\text { dehydrogenase }\end{array}$ & Up & 69 & 54530 & 6.57 & 9 & 21 & - \\
\hline P10860 & DHE3_RAT & $\begin{array}{l}\text { Glutamate dehydrogenase } 1, \\
\text { mitochondrial }\end{array}$ & Landmark & 192 & 61719 & 8.05 & 27 & 36 & - \\
\hline \multicolumn{10}{|c|}{ Fatty acid metabolism } \\
\hline P35571 & GPDM_RAT & $\begin{array}{l}\text { Glycerol-3-phosphate dehydrogenase, } \\
\text { mitochondrial }\end{array}$ & Absent & 123 & 81549 & 6.18 & 12 & 19 & - \\
\hline $\mathrm{P} 15650$ & ACADL_RAT & $\begin{array}{l}\text { Long-chain specific acyl-CoA } \\
\text { dehydrogenase }\end{array}$ & Up & 90 & 48242 & 7.63 & 10 & 18 & - \\
\hline \multicolumn{10}{|c|}{ Proteins against oxidative stress } \\
\hline P07632 & SODC_RAT & Superoxide dismutase $[\mathrm{Cu}-\mathrm{Zn}]$ & Absent & 134 & 16073 & 5.88 & 8 & 48 & - \\
\hline Q63081 & PDIA6_RAT & Protein disulfide isomerase A6 & Absent & 109 & 48542 & 5 & 8 & 23 & - \\
\hline Q8R4A1 & ERO1A_RAT & ERO1-like protein alpha & Absent & 92 & 54839 & 5.83 & 7 & 19 & - \\
\hline P35704 & PRDX2_RAT & Peroxiredoxin 2 & Landmark & 91 & 21941 & 5.34 & 7 & 31 & - \\
\hline P11598 & PDIA3_RAT & Protein disulfide isomerase 3 & Landmark & 320 & 57044 & 5.88 & 33 & 56 & - \\
\hline P54001 & P4HA1_RAT & Prolyl 4-hydroxylase subunit alpha-1 & Landmark & 237 & 61202 & 5.63 & 20 & 36 & - \\
\hline \multicolumn{10}{|c|}{ Proteasom, ubiquitin system } \\
\hline Q9JHW0 & PSB7_RAT & Proteasome subunit beta type- 7 & Absent & 61 & 30250 & 8.13 & 5 & 12 & - \\
\hline Q6AXR4 & HEXB_RAT & Beta-hexosaminidase subunit beta & Up & 92 & 61888 & 8.02 & 11 & 23 & + \\
\hline
\end{tabular}

Signal transduction

$13 \quad 48 \quad+$


TABLE 1: Continued.

\begin{tabular}{|c|c|c|c|c|c|c|c|c|c|}
\hline Acc. No. & Entry name & Protein name & Expression & Score & MW & pI & Qm & Sc & Mixed \\
\hline \multicolumn{10}{|c|}{ Transcription } \\
\hline Q8VHV7 & HNRH1_RAT & $\begin{array}{l}\text { Heterogeneous nuclear } \\
\text { ribonucleoprotein } \mathrm{H}\end{array}$ & Up & 72 & 49442 & 5.7 & 11 & 28 & - \\
\hline P60123 & RUVB1_RAT & $\begin{array}{l}\text { RuvB like } 1,49 \mathrm{kDa} \text { TATA box-binding } \\
\text { protein-interacting protein }\end{array}$ & Down & 88 & 50524 & 6.02 & 6 & 19 & - \\
\hline Q9JMJ4 & PRP19_RAT & Pre-mRNA-processing factor 19 & Down & 129 & 55661 & 6.14 & 13 & 28 & - \\
\hline \multicolumn{10}{|c|}{ Translation } \\
\hline Q4KM49 & SYYC_RAT & Tyrosyl-tRNA synthetase & Down & 175 & 59420 & 6.57 & 16 & 29 & - \\
\hline P38983 & RSSA_RAT & $\begin{array}{l}\text { 40S ribosomal protein SA, laminin } \\
\text { receptor } 1, \mathrm{LRP} / \mathrm{LR} \text {; laminin-binding } \\
\text { protein precursor } \mathrm{p} 40\end{array}$ & Down & 51 & 32917 & 4.8 & 4 & 17 & - \\
\hline P05197 & EF2_RAT & Elongation factor 2 & Landmark & 135 & 96192 & 6.41 & 18 & 22 & - \\
\hline Q6P9U8 & EIF3H_RAT & $\begin{array}{l}\text { Eukaryotic translation initiation factor } \\
3 \text { subunit } \mathrm{H}\end{array}$ & Landmark & 132 & 40051 & 6.2 & 10 & 36 & - \\
\hline \multicolumn{10}{|c|}{ Unknown function } \\
\hline Q4FZT0 & STML2_RAT & Stomatin like protein 2 & UP & 85 & 38504 & 8.74 & 6 & 21 & - \\
\hline
\end{tabular}

First column: Acc. No. (mascot identification). Second column: entry name (swiss-prot identification). Third column: protein title. Fourth column: expression (categories: absent, up, down, landmark). Fifth column: score (mascot-score). Sixth column: MW (theoretical protein mass [Da]). Seventh column: pI (theoretical isoelectric point). Eighth column: Qm (query matches). Ninth column: Sc (sequence covery [\%]). Tenth column: mixed (mixed spot [+/-]).

striatum of a fetal rat [11]. Annexin A5 is a $35 \mathrm{kD}$ protein and was first discovered as an anticoagulant-acting protein in blood vessels [27]. It is also called annexin-5, annexin $\mathrm{V}$, or lipocortin V (UniProtKP/Swiss-Prot). The annexins are a superfamily of calcium ions- and phospholipid-binding proteins with highly conserved binding domains [28-30]. Annexin I, III, and V inhibit the activity of phospholipase A2 (PLA2) which acts as a key enzyme in inflammation and cytotoxicity in the CNS [31]. The activated PLA2 cleaves membrane phospholipids and leads to cell death [32]. Simultaneously precursor molecules of eicosanoids and plateletactivating factor (PAF) are released, which promote the production of reactive oxygen species. There are more than 27 isoforms of PLA2 in mammals which can be divided into four main groups [33]: cytosolic PLA2, secretory PLA2, calcium ion-independent PLA2, and PAF acetylhydrolases. Especially the soluble PLA2 seems to play a key role in neurodegenerative diseases such as Alzheimer's disease [34], multiple sclerosis $[35,36], \mathrm{PD}[37,38]$, and in the response to spinal cord injuries [39].

Furthermore, it could be shown that annexin V plays an important role as a regulator of apoptosis [40]. Apoptotic cells display phosphatidylserine on the outer side of the cell membrane, which serves as a signal for phagocytosis by macrophages [41]. However this process is not only limited solely to apoptotic cells but also occurs in the context of nonapoptotic cell death programs [42] as well as in the aging of red blood cells and the activation of platelets [43]. Healthy cells prevent the exposure of phosphatidylserine on their cell surface by energy-dependent processes. Annexin V binds in the presence of calcium ions with high affinity to the negatively charged phosphatidylserine [40]. Annexin A5 is therefore used widely as a marker for the study of apoptosis in vitro, in animal models, and even in vivo in patients with cardiovascular disease or cancer.

Annexins I and $\mathrm{V}$ were also found to have neurotrophic effects on cultured neurons $[44,45]$. Han et al. [46] studied the effects of the annexins II and $\mathrm{V}$ on the survival of neurons and astrocytes in vitro. They could show that these two proteins are essential for the survival and the growth of neurites of developing cortical neurons, for the survival of glial cells, and for the protection of neurons and glial cells against peroxides and hypoxic injury. Whether this observation is related to the inhibition of PLA2 by annexin $\mathrm{V}$ has to be clarified.

In the present study, the absolute number of CSM14.1 cells per petri dish is reduced by more than half during differentiation (see also Haas et al. [21]). The observed increase in the expression of annexin A5 during differentiation indicates that cell death might occur by apoptosis. However, this increase might also be explained by the previously described effect of annexin A5 for the development and survival of neurons and glia cells. The cell line CSM14.1 seems to be able to respond to an elevated level of cell stress due to the change of the environment with an increased expression of annexin A5.

Another protein with increased expression in differentiated CSM14.1 cells is cytoplasmic actin, a globular protein (G-actin), which forms in the presence of magnesium and calcium ions a microtubule independent cytoskeleton and is a fundamental part of the contractile apparatus of muscle cells. It also occurs in high concentrations in nonmuscle cells [47]. There is a dynamic equilibrium between monomeric and polymeric (filamentous) actin (F-actin). The polymerization is carried out at the positive end of a actin filament by addition of ATP complexed G-actin and the cleavage of Gactin occurs from the minus end. The structure of the actin 


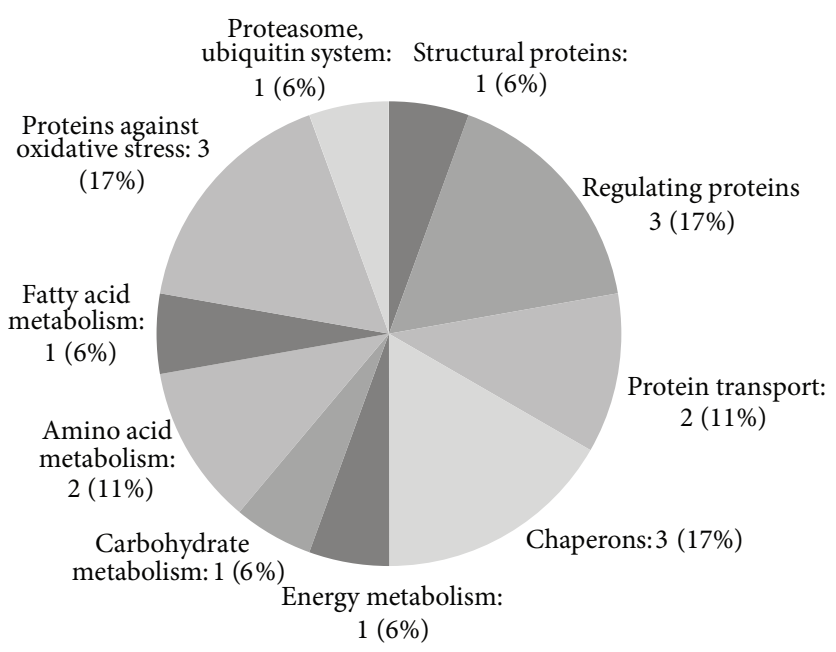

(a)

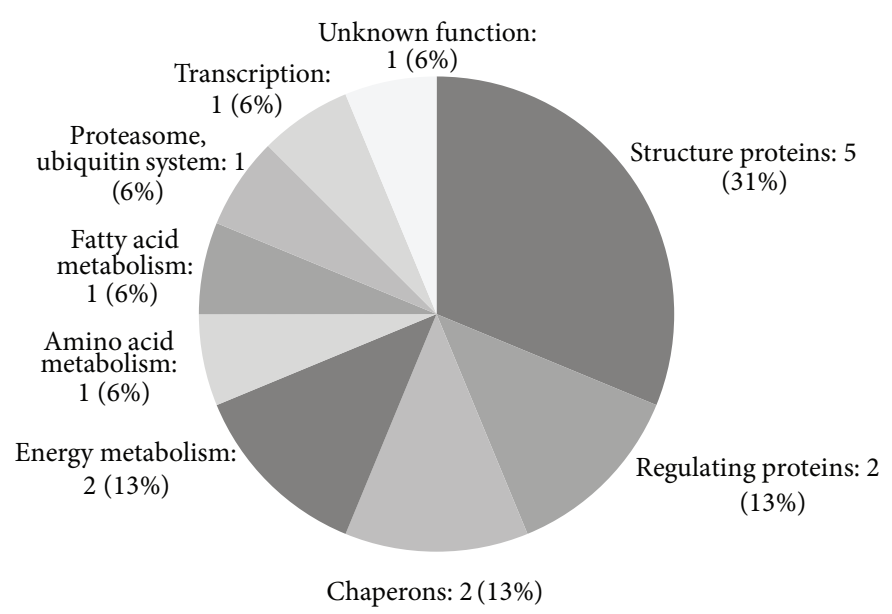

(b)

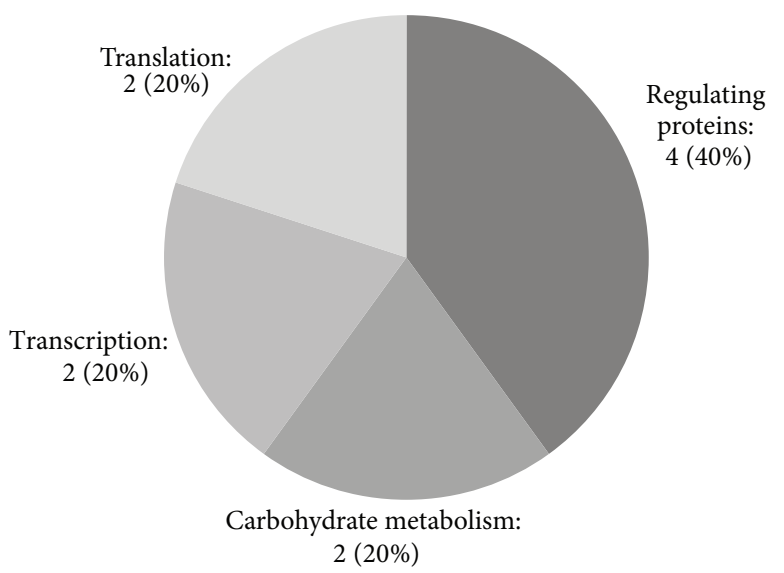

(c)

FIGURE 4: Relative quantitative distribution of functional protein groups only detected in differentiated CSM14.1 cells (a) and of proteins with a higher (b) or lower (c) expression compared to undifferentiated CSM14.1 cells. The majority of proteins only detected in differentiated CSM14.1-cells (a) were classified as regulating proteins (17\%), chaperons (17\%), and proteins against oxidative stress (17\%). Upregulated proteins (b) belonged primarily to structural proteins (31\%), regulating proteins (13\%), chaperons (13\%), and proteins of energy metabolism $(13 \%)$. Proteins with a lower expression in differentiated CSM14.1 cells (c) were classified as regulating proteins (40\%), proteins associated with transcription (20\%) and translation (20\%), and carbohydrate metabolism (20\%).

filament was described by Holmes et al. [48]. Several proteins regulate the dynamic equilibrium through the stabilization of F-actin or the promotion of G-actin cleavage. One of these proteins is gelsolin $(86 \mathrm{kD})$ which shows in this study an increased expression in differentiated CSM14.1 cells. It was first isolated in macrophages from the rabbit lung [49] and plays an important role in actin-based cell motility.

Depending on calcium ions gelsolin prevents further actin polymerization by covering the plus ends [49-53]. On the other hand it may encourage the formation of filaments by binding two monomers and therefore functions as a nucleus. The binding of phosphatidylinositol 4-phosphate or phosphatidylinositol-4,5-bisphosphate to gelsolin solves its binding to the plus end of the actin filament, so that a quick attachment of further monomers to this filament is possible $[54,55]$. Gelsolin also plays an important role in the formation of neurites by regulation of actin polymerisation.
PC12 cells that overexpress gelsolin develop longer neurites with a greater motility than PC12 wild type cells [56].

Gelsolin seems to ensure the stability of actin filaments [57]. Dong et al. showed that after entorhinal deafferentation of the hippocampus a significant increase of gelsolin expression could be observed in activated microglia and astrocytes [58]. Another protein with increased expression in differentiated CSM14.1 cells is the $48 \mathrm{kD}$ actin related protein 3 (Arp3). A complex of Arp3 and actin related protein 2 (Arp2/3) allows the formation of branched actin filaments [59].

Physiologically associated with actin is the $68 \mathrm{kD}$ protein moesin (membrane-organizing extension spike protein), which is detectable only in differentiated CSM14.1 cells. Moesin belongs together with ezrin and radixin to the family of ERM (ezrin-radixin-moesin) proteins which are highly conserved during evolution [60]. The ERM proteins play 
an important role in the formation and maintenance of cell shape within growth and motility of cells $[61,62]$. The C-terminal domain of these proteins binds to actin [6366]. The N-terminal domain, called the FERM (band 4.1, ezrin, radixin, moesin homology domain [67]) binds to the cytoplasmic domain of numerous integral membrane proteins. By intramolecular combination of the $\mathrm{N}$ - and $\mathrm{C}$ terminus an inactive conformation is created, which prevents the binding of other proteins, such as F-actin [64]. At the Cterminus, there is a conserved threonine residue whose phosphorylation results in a conformational change and allows the association with other proteins [68]. This phosphorylation is executed, for example, by the Rho kinase [69]. The ratio between phosphorylated (pERM) and nonphosphorylated ERM proteins is important for the formation of neurites by neurons. In addition to the Rho kinase the LRRK2 (leucinerich repeat protein kinase 2) is of great importance. Mutations in this enzyme are the cause of autosomal dominant forms of PD [70, 71]. This kinase is closely related to the preservation and the growth of neurites and therefore important for the development of neurons [72]. It is assumed that the formation of an axon from a neurite occurs when the stability of the F-actin decreases and the stability of microtubules increases $[73,74]$.

Taken together, proteins associated with the cytoskeleton which are necessary for morphological differentiation (cell processes) as well as migration in vivo after intracerebral transplantation $[10,21]$ are correlated with an increase of their differential expression. In further experiments protein validation and interactions could be performed with regard to the proteins detected here.

\section{Conclusion}

The changes in the expression pattern of the proteins discussed above are consistent with the previous findings for the cell line CSM14.1. The increased expression of actin, gelsolin, and Arp 3 by differentiated cells and the expression of moesin only by differentiated CSM14.1 might be related and could be evidence for a neuronal development of these cells. These findings are in agreement with the morphological change of the cells during differentiation.

The detection of the proteins nestin (dimer: 198$260 \mathrm{kDa})$, GFAP $(50 \mathrm{kD})$, NeuN (46-48 kD), and TH (60$68 \mathrm{kD})$ was not achieved with the selected differential experimental setting. Thus, a direct comparison of the results of both methods used in this study is not possible. Further investigation should include a protein mapping of undifferentiated and differentiated CSM14.1 cells to analyze spots which did not fulfill our established criteria. A fractional analysis of the individual cell compartments might also be a promising approach. Especially integrated membrane proteins might be a promising research objective in terms of neuronal and especially dopaminergic differentiation.

The results obtained in this study confirm the suitability of the cell line CSM14.1 as a model for the study of neuronal and dopaminergic differentiation in rats.

\section{Conflict of Interests}

The authors certify that there is no conflict of interests with any financial organization regarding the material used and/or discussed in the paper.

\section{Authors' Contribution}

B. Weiss and S. Haas have contributed equally to this work.

\section{Acknowledgment}

The authors acknowledge Antje Schümann (Department of Anatomy) for skillful technical assistance.

\section{References}

[1] O. Lindvall and Z. Kokaia, "Prospects of stem cell therapy for replacing dopamine neurons in Parkinson's disease," Trends in Pharmacological Sciences, vol. 30, no. 5, pp. 260-267, 2009.

[2] O. Lindvall and A. Björklund, "Cell therapeutics in parkinson's disease," Neurotherapeutics, vol. 8, no. 4, pp. 539-548, 2011.

[3] U. Pfisterer, A. Kirkeby, O. Torper et al., "Direct conversion of human fibroblasts to dopaminergic neurons," Proceedings of the National Academy of Sciences of the United States of America, vol. 108, no. 25, pp. 10343-10348, 2011.

[4] A. Martínez-Serrano and A. Björklund, "Immortalized neural progenitor cells for CNS gene transfer and repair," Trends in Neurosciences, vol. 20, no. 11, pp. 530-538, 1997.

[5] M. M. Durand, D. C. Chugani, M. Mahmoudi, and M. E. Phelps, "Characterization of neuron-like cell line immortalized from primary rat mesencephalon cultures," Society for Neuroscience Abstracts, vol. 16, p. 40, 1990.

[6] L. T. Zhong, T. Sarafian, D. J. Kane et al., "bcl-2 inhibits death of central neural cells induced by multiple agents," Proceedings of the National Academy of Sciences of the United States of America, vol. 90, no. 10, pp. 4533-4537, 1993.

[7] R. Anton, J. H. Kordower, N. T. Maidment et al., "Neuraltargeted gene therapy for rodent and primate hemiparkinsonism," Experimental Neurology, vol. 127, no. 2, pp. 207-218, 1994.

[8] R. Anton, J. H. Kordower, D. J. Kane, C. H. Markham, and D. E. Bredesen, "Neural transplantation of cells expressing the antiapoptotic gene bcl-2," Cell Transplantation, vol. 4, no. 1, pp. 49$54,1995$.

[9] S. J. P. Haas and A. Wree, "Dopaminergic differentiation of the Nurrl-expressing immortalized mesencephalic cell line CSM14.1 in vitro," Journal of Anatomy, vol. 201, no. 1, pp. 61-69, 2002.

[10] S. J. P. Haas, S. Beckmann, S. Petrov, C. Andressen, A. Wree, and O. Schmitt, "Transplantation of immortalized mesencephalic progenitors (CSM14.1 cells) into the neonatal Parkinsonian rat caudate putamen," Journal of Neuroscience Research, vol. 85, no. 4, pp. 778-786, 2007.

[11] R. Hoffrogge, S. Beyer, R. Hübner et al., "2-DE profiling of GDNF overexpression-related proteome changes in differentiating ST14A rat progenitor cells," Proteomics, vol. 7, no. 1, pp. 33-46, 2007.

[12] C. Winkler, R. A. Fricker, M. A. Gates et al., "Incorporation and glial differentiation of mouse EGF-responsive neural progenitor cells after transplantation into the embryonic rat brain," Molecular and Cellular Neurosciences, vol. 11, no. 3, pp. 99-116, 1998. 
[13] E. Cattaneo and L. Conti, "Generation and characterization of embryonic striatal conditionally immortalized ST14A cells," Journal of Neuroscience Research, vol. 53, no. 2, pp. 223-234, 1998.

[14] H. J. G. Gundersen, "Estimators of the number of objects per area unbiased by edge effects," Microscopica Acta, vol. 81, no. 2, pp. 107-117, 1978.

[15] G. Lessner, O. Schmitt, S. J. P. Haas et al., "Differential proteome of the striatum from hemiparkinsonian rats displays vivid structural remodeling processes," Journal of Proteome Research, vol. 9, no. 9, pp. 4671-4687, 2010.

[16] P. S. Vernon and D. E. Griffin, "Characterization of an in vitro model of alphavirus infection of immature and mature neurons," Journal of Virology, vol. 79, no. 6, pp. 3438-3447, 2005.

[17] L. F. Eng, R. S. Ghirnikar, and Y. L. Lee, "Glial Fibrillary Acidic Protein: GFAP-thirty-one years (1969-2000)," Neurochemical Research, vol. 25, no. 9-10, pp. 1439-1451, 2000.

[18] C. N. Svendsen, A. Bhattacharyya, and Y. T. Tai, "Neurons from stem cells: preventing an identity crisis," Nature Reviews Neuroscience, vol. 2, no. 11, pp. 831-834, 2001.

[19] J. M. Polak and S. van Noorden, An Introduction to Immunocytochemistry: Current Techniques and Problems, Oxford University Press, Oxford, UK, 1992.

[20] P. Kermer, M. Krajewska, J. M. Zapata et al., "Bag1 is a regulator and marker of neuronal differentiation," Cell Death and Differentiation, vol. 9, no. 4, pp. 405-413, 2002.

[21] S. J.-P. Haas, S. Petrov, G. Kronenberg, O. Schmitt, and A. Wree, "Orthotopic transplantation of immortalized mesencephalic progenitors (CSM14.1 cells) into the substantia nigra of hemiparkinsonian rats induces neuronal differentiation and motoric improvement," Journal of Anatomy, vol. 212, no. 1, pp. 19-30, 2008.

[22] S. Udenfriend and J. B. Wyngaarden, "Precursors of adrenal epinephrine and norepinephrine in vivo," Biochimica et Biophysica Acta, vol. 20, no. 1, pp. 48-52, 1956.

[23] E. Y. Levin, B. Levenberg, and S. Kaufman, "The enzymatic conversion of 3,4-dihydroxyphenylethylamine to norepinephrine," The Journal of Biological Chemistry, vol. 235, pp. 2080-2086, 1960.

[24] P. McCaffery and U. C. Drager, "High levels of a retinoic acidgenerating dehydrogenase in the meso- telencephalic dopamine system," Proceedings of the National Academy of Sciences of the United States of America, vol. 91, no. 16, pp. 7772-7776, 1994.

[25] N. S. K. Haque, C. J. Leblanc, and O. Isacson, "Differential dissection of the rat E16 ventral mesencephalon and survival and reinnervation of the 6-OHDA-lesioned striatum by a subset of aldehyde dehydrogenase-positive TH neurons," Cell Transplantation, vol. 6, no. 3, pp. 239-248, 1997.

[26] Å. Wallén, R. H. Zetterström, L. Solomin, M. Arvidsson, L. Olson, and T. Perlmann, "Fate of mesencephalic AHD2expressing dopamine progenitor cells in Nurrl mutant mice," Experimental Cell Research, vol. 253, no. 2, pp. 737-746, 1999.

[27] C. P. M. Reutelingsperger, G. Hornstra, and H. C. Hemker, "Isolation and partial purification of a novel anticoagulant from arteries of human umbilical cord," European Journal of Biochemistry, vol. 151, no. 3, pp. 625-629, 1985.

[28] R. J. Flower and N. J. Rothwell, "Lipocortin-1: cellular mechanisms and clinical relevance," Trends in Pharmacological Sciences, vol. 15, no. 3, pp. 71-76, 1994.

[29] M. Perretti, "Lipocortin-derived peptides," Biochemical Pharmacology, vol. 47, no. 6, pp. 931-938, 1994.
[30] P. Raynal and H. B. Pollard, "Annexins: the problem of assessing the biological role for a gene family of multifunctional calciumand phospholipid-binding proteins," Biochimica et Biophysica Acta, vol. 1197, no. 1, pp. 63-93, 1994.

[31] J. V. Bonventre, "Roles of phospholipases A2 in brain cell and tissue injury associated with ischemia and excitotoxicity," Journal of Lipid Mediators and Cell Signalling, vol. 17, no. 1, pp. 71-79, 1997.

[32] J. Klein, "Membrane breakdown in acute and chronic neurodegeneration: focus on choline-containing phospholipids," Journal of Neural Transmission, vol. 107, no. 8-9, pp. 1027-1063, 2000.

[33] W. L. Titsworth, N. K. Liu, and X. M. Xu, "Role of secretory phospholipase A2 in CNS inflammation: implications in traumatic spinal cord injury," CNS and Neurological Disorders, vol. 7, no. 3, pp. 254-269, 2008.

[34] G. S. D. Moses, M. D. Jensen, L. F. Lue et al., "Secretory PLA2IIA: a new inflammatory factor for Alzheimer's disease," Journal of Neuroinflammation, vol. 3, p. 28, 2006.

[35] S. Marusic, M. W. Leach, J. W. Pelker et al., "Cytosolic phospholipase A2 $\alpha$-deficient mice are resistant to experimental autoimmune encephalomyelitis," Journal of Experimental Medicine, vol. 202, no. 6, pp. 841-851, 2005.

[36] F. Pinto, T. Brenner, P. Dan, M. Krimsky, and S. Yedgar, "Extracellular phospholipase A2 inhibitors suppress central nervous system inflammation," Glia, vol. 44, no. 3, pp. 275-282, 2003.

[37] T. Hayakawa, M. C. J. Chang, S. I. Rapoport, and N. M. Appel, "Selective dopamine receptor stimulation differentially affects $[3 \mathrm{H}]$ arachidonic acid incorporation, a surrogate marker for phospholipase A2-mediated neurotransmitter signal transduction, in a rodent model of Parkinson's disease," Journal of Pharmacology and Experimental Therapeutics, vol. 296, no. 3, pp. 1074-1084, 2001.

[38] M. Tariq, H. A. Khan, K. A. Moutaery, and S. A. Deeb, "Protective effect of quinacrine on striatal dopamine levels in 6OHDA and MPTP models of Parkinsonism in rodents," Brain Research Bulletin, vol. 54, no. 1, pp. 77-82, 2001.

[39] N. Liu, S. Han, P. H. Lu, and X. M. Xu, "Upregulation of annexins I, II, and V after traumatic spinal cord injury in adult rats," Journal of Neuroscience Research, vol. 77, no. 3, pp. 391-401, 2004.

[40] C. P. M. Reutelingsperger and W. L. van Heerde, "Annexin $\mathrm{V}$, the regulator of phosphatidylserine-catalyzed inflammation and coagulation during apoptosis," Cellular and Molecular Life Sciences, vol. 53, no. 6, pp. 527-532, 1997.

[41] V. A. Fadok, D. R. Voelker, P. A. Campbell, J. J. Cohen, D. L. Bratton, and P. M. Henson, "Exposure of phosphatidylserine on the surface of apoptotic lymphocytes triggers specific recognition and removal by macrophages," The Journal of Immunology, vol. 148, no. 7, pp. 2207-2216, 1992.

[42] M. Leist and M. Jäättelä, "Four deaths and a funeral: from caspases to alternative mechanisms," Nature Reviews Molecular Cell Biology, vol. 2, no. 8, pp. 589-598, 2001.

[43] R. F. A. Zwaal and A. J. Schroit, "Pathophysiologic implications of membrane phospholipid asymmetry in blood cells," Blood, vol. 89, no. 4, pp. 1121-1132, 1997.

[44] N. Takei, K. Ohsawa, Y. Imaia, H. Nakao, A. Iwasaki, and S. Kohsaka, "Neurotrophic effects of annexin V on cultured neurons from embryonic rat brain," Neuroscience Letters, vol. 171, no. 1-2, pp. 59-62, 1994. 
[45] H. Mizuno, K. Asai, K. Fujita et al., "Neurotrophic action of lipocortin 1 derived from astrocytes on cultured rat cortical neurons," Molecular Brain Research, vol. 60, no. 1, pp. 28-39, 1998.

[46] S. Han, K.-H. Zhang, P. H. Lu, and X. M. Xu, "Effects of annexins II and V on survival of neurons and astrocytes in vitro," Acta Pharmacologica Sinica, vol. 25, no. 5, pp. 602-610, 2004.

[47] S. Hatano and F. Oosawa, "Isolation and characterization of plasmodium actin," Biochimica et Biophysica Acta, vol. 127, no. 2, pp. 488-498, 1966.

[48] K. C. Holmes, D. Popp, W. Gebhard, and W. Kabsch, "Atomic model of the actin filament," Nature, vol. 347 , no. 6288, pp. 4449, 1990.

[49] H. L. Yin and T. P. Stossel, "Control of cytoplasmic actin gelsol transformation by gelsolin, a calcium-dependent regulatory protein," Nature, vol. 281, no. 5732, pp. 583-586, 1979.

[50] H. L. Yin, J. H. Hartwig, K. Maruyama, and T. P. Stossel, " $\mathrm{Ca}^{2+}$ control of actin filament length. Effects of macrophage gelsolin on actin polymerization," Journal of Biological Chemistry, vol. 256, no. 18, pp. 9693-9697, 1981.

[51] J. A. Lamb, P. G. Allen, B. Y. Tuan, and P. A. Janmey, "Modulation of gelsolin function. Activation at low $\mathrm{pH}$ overrides $\mathrm{Ca}^{2+}$ requirement," Journal of Biological Chemistry, vol. 268, no. 12, pp. 8999-9004, 1993.

[52] R. C. Robinson, M. Mejillano, V. P. Le, L. D. Burtnick, H. L. Yin, and S. Choe, "Domain movement in gelsolin: a calciumactivated switch," Science, vol. 286, no. 5446, pp. 1939-1942, 1999.

[53] L. D. Burtnick, D. Urosev, E. Irobi, K. Narayan, and R. C. Robinson, "Structure of the N-terminal half of gelsolin bound to actin: roles in severing, apoptosis and FAF," The EMBO Journal, vol. 23, no. 14, pp. 2713-2722, 2004.

[54] P. A. Jammey, K. Iida, H. L. Yin, and T. P. Stossel, "Polyphosphoinositide micelles and polyphosphoinositide-containing vesicles dissociate endogenous gelsolin-actin complexes and promote actin assembly from the fast-growing end of actin filaments blocked by gelsolin," Journal of Biological Chemistry, vol. 262, no. 25, pp. 12228-12236, 1987.

[55] P. A. Janmey and T. P. Stossel, "Modulation of gelsolin function by phosphatidylinositol 4,5 bisphosphate," Nature, vol. 325, no. 6102, pp. 362-364, 1987.

[56] E. J. Furnish, W. Zhou, C. C. Cunningham, J. A. Kas, and C. E. Schmidt, "Gelsolin overexpression enhances neurite outgrowth in PC12 cells," The FEBS Letters, vol. 508, no. 2, pp. 282-286, 2001.

[57] E. N. Star, D. J. Kwiatkowski, and V. N. Murthy, "Rapid turnover of actin in dendritic spines and its regulation by activity," Nature Neuroscience, vol. 5, no. 3, pp. 239-246, 2002.

[58] J. H. Dong, G. X. Ying, X. Liu et al., "Lesion-induced gelsolin upregulation in the hippocampus following entorhinal deafferentation," Hippocampus, vol. 16, no. 1, pp. 91-100, 2006.

[59] R. D. Mullins, J. A. Heuser, and T. D. Pollard, "The interaction of Arp $2 / 3$ complex with actin: nucleation, high affinity pointed end capping, and formation of branching networks of filaments," Proceedings of the National Academy of Sciences of the United States of America, vol. 95, no. 11, pp. 6181-6186, 1998.

[60] W. T. Lankes and H. Furthmayr, "Moesin: a member of the protein 4.1-talin-ezrin family of proteins," Proceedings of the National Academy of Sciences of the United States of America, vol. 88 , no. 19 , pp. 8297-8301, 1991.
[61] P. Mangeat, C. Roy, and M. Martin, "ERM proteins in cell adhesion and membrane dynamics," Trends in Cell Biology, vol. 9, no. 5, pp. 187-192, 1999.

[62] A. Bretscher, K. Edwards, and R. G. Fehon, "ERM proteins and merlin: integrators at the cell cortex," Nature Reviews Molecular Cell Biology, vol. 3, no. 8, pp. 586-599, 2002.

[63] M. Algrain, O. Turunen, A. Vaheri, D. Louvard, and M. Arpin, "Ezrin contains cytoskeleton and membrane binding domains accounting for its proposed role as a membrane-cytoskeletal linker," Journal of Cell Biology, vol. 120, no. 1, pp. 129-140, 1993.

[64] O. Turunen, T. Wahlström, and A. Vaheri, "Ezrin has a COOHterminal actin-binding site that is conserved in the ezrin protein family," Journal of Cell Biology, vol. 126, no. 6, pp. 1445-1453, 1994.

[65] M. D. Henry, C. G. Agosti, and F. Solomon, "Molecular dissection of radixin: distinct and interdependent functions of the amino- and carboxy-terminal domains," Journal of Cell Biology, vol. 129, no. 4, pp. 1007-1022, 1995.

[66] K. Pestonjamasp, M. R. Amieva, C. P. Strassel, W. M. Nauseef, H. Furthmayr, and E. J. Luna, "Moesin, ezrin, and p205 are actin-binding proteins associated with neutrophil plasma membranes," Molecular Biology of the Cell, vol. 6, no. 3, pp. 247259, 1995.

[67] A. H. Chishti, A. C. Kim, S. M. Marfatia et al., "The FERM domain: a unique module involved in the linkage of cytoplasmic proteins to the membrane," Trends in Biochemical Sciences, vol. 23, no. 8, pp. 281-282, 1998.

[68] M. Hirao, N. Sato, T. Kondo et al., "Regulation mechanism of ERM (ezrin/radixin/moesin) protein/plasma membrane association: possible involvement of phosphatidylinositol turnover and rho-dependent signaling pathway," Journal of Cell Biology, vol. 135, no. 1, pp. 37-51, 1996.

[69] T. Matsui, M. Maeda, Y. Doi et al., "Rho-kinase phosphorylates $\mathrm{COOH}$-terminal threonines of ezrin/radixin/moesin (ERM) proteins and regulates their head-to-tail association," Journal of Cell Biology, vol. 140, no. 3, pp. 647-657, 1998.

[70] A. Zimprich, S. Biskup, P. Leitner et al., "Mutations in LRRK2 cause autosomal-dominant parkinsonism with pleomorphic pathology," Neuron, vol. 44, no. 4, pp. 601-607, 2004.

[71] C. Paisán-Ruíz, S. Jain, E. W. Evans et al., "Cloning of the gene containing mutations that cause PARK8-linked Parkinson's disease," Neuron, vol. 44, no. 4, pp. 595-600, 2004.

[72] D. MacLeod, J. Dowman, R. Hammond, T. Leete, K. Inoue, and A. Abeliovich, "The familial parkinsonism gene LRRK2 regulates neurite process morphology," Neuron, vol. 52, no. 4, pp. 587-593, 2006.

[73] F. Bradke and C. G. Dotti, "The role of local actin instability in axon formation," Science, vol. 283, no. 5409, pp. 1931-1934, 1999.

[74] F. Bradke and C. G. Dotti, "Changes in membrane trafficking and actin dynamics during axon formation in cultured hippocampal neurons," Microscopy Research and Technique, vol. 48, no. 1, pp. 3-11, 2000. 

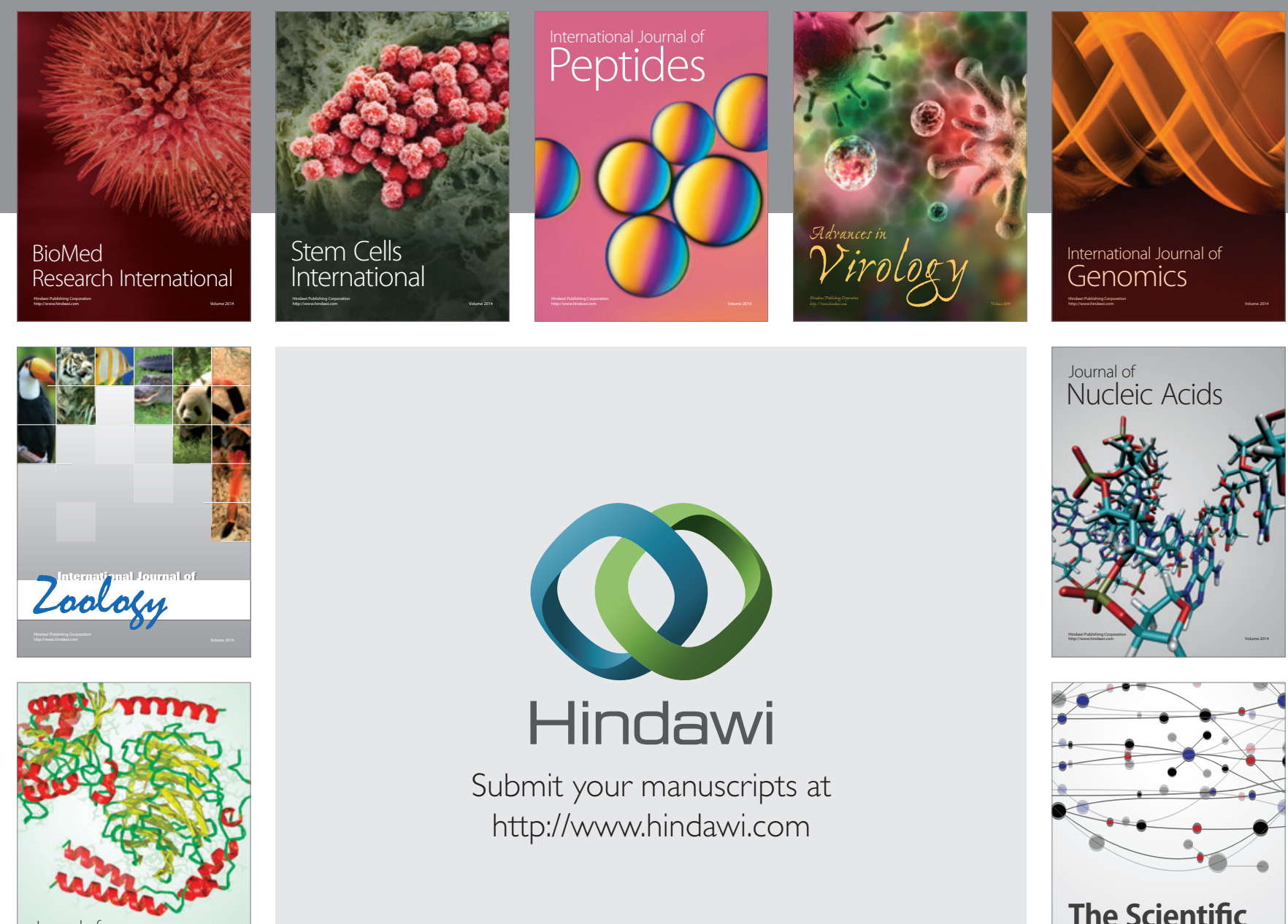

Submit your manuscripts at

http://www.hindawi.com

Journal of
Signal Transduction
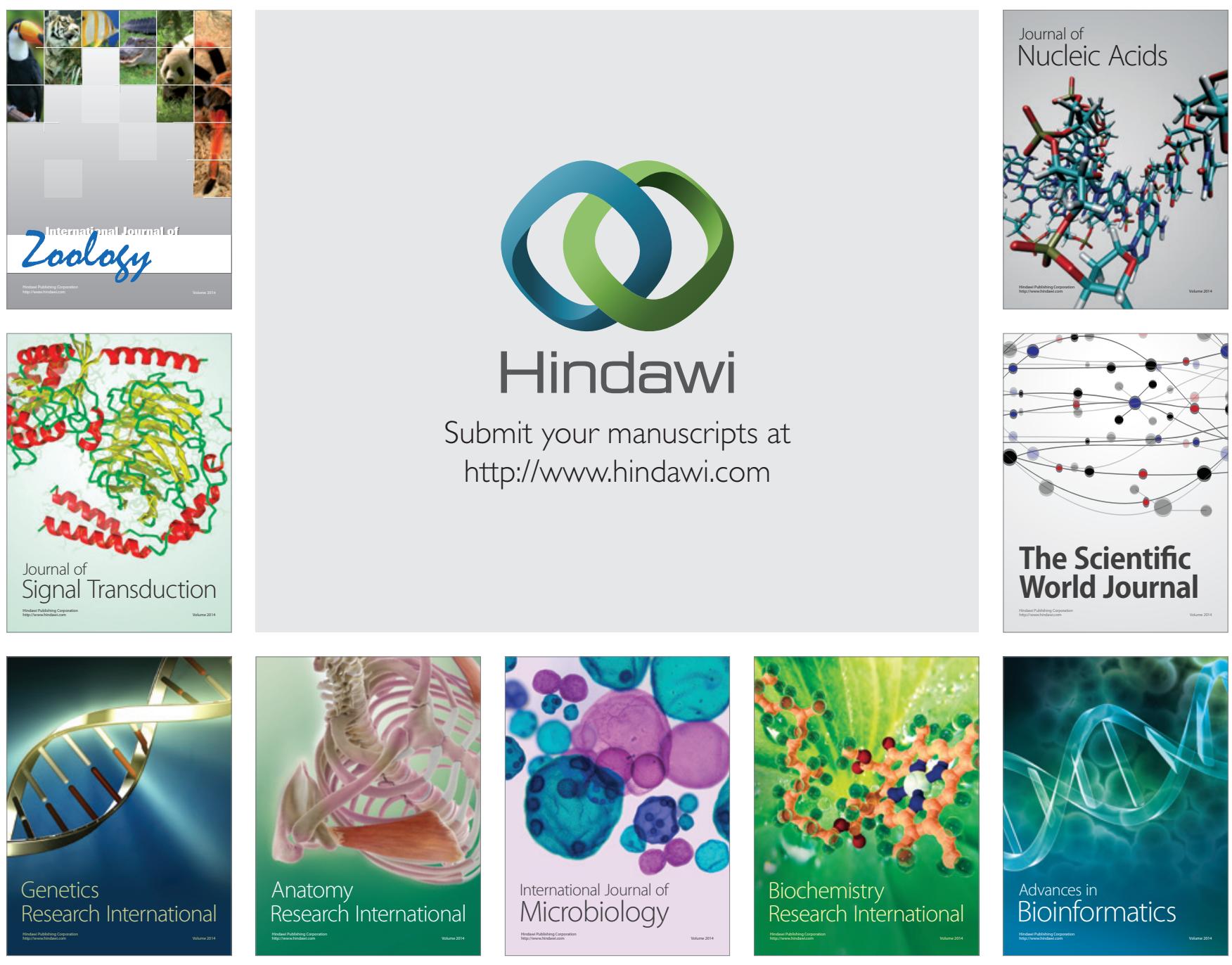

The Scientific World Journal
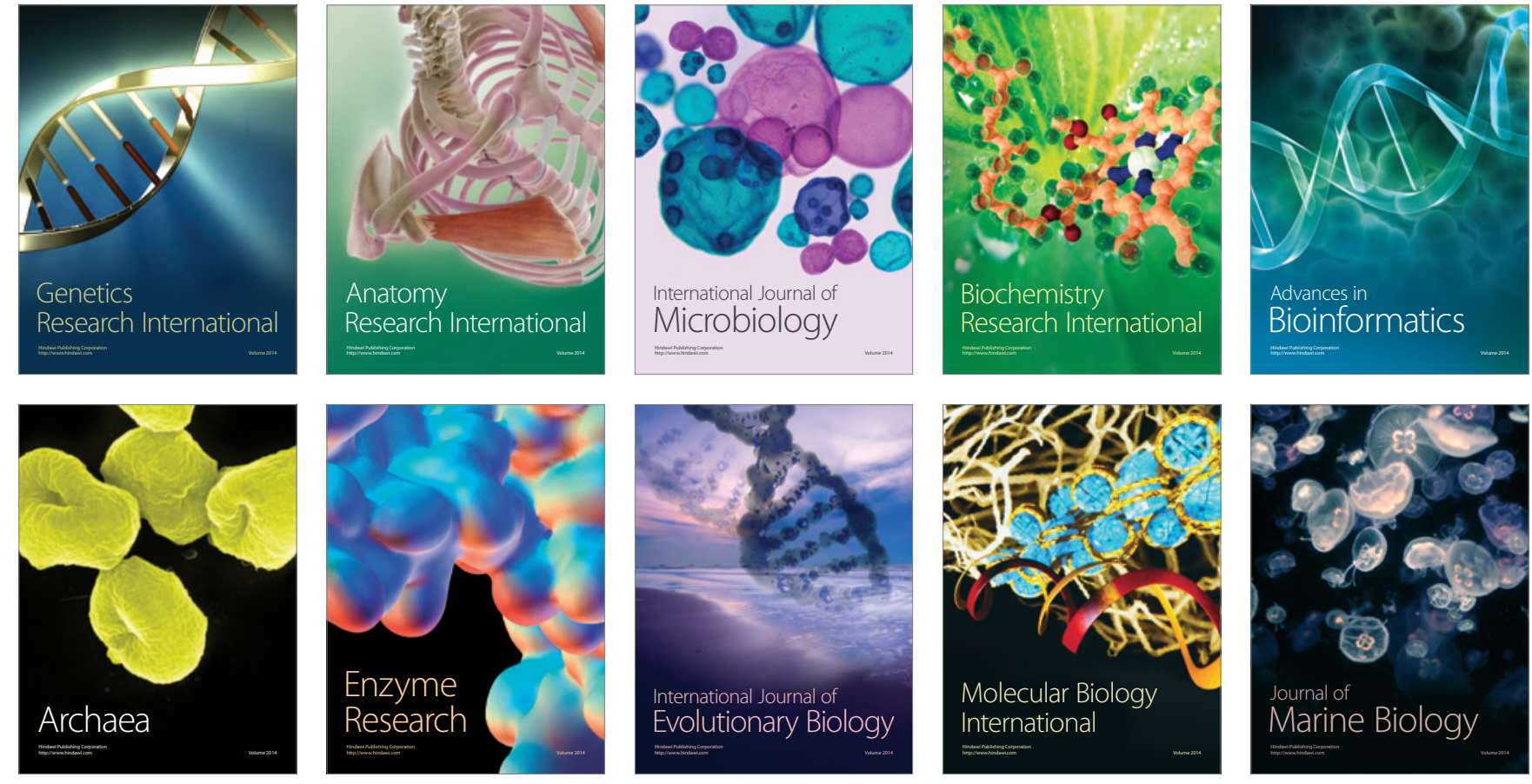